Article

\title{
Towards a Sustainability Education Framework: Challenges, Concepts and Strategies-The Contribution from Urban Planning Perspectives
}

\section{Yosef Jabareen}

Faculty of Architecture and Town Planning, Technion-Israel Institute of Technology, Haifa 32000, Israel; E-Mail: jabareen@technion.ac.il; Tel.: +972-5-2865-5336; Fax: +972-4-8294-0617

Received: 5 July 2012; in revised form: 30 August 2012 / Accepted: 4 September 2012 /

Published: 14 September 2012

\begin{abstract}
Education for sustainability is becoming a critical component in achieving a sustainable life and protecting our planet and human habitats. However, a review of the sustainability literature reveals a great deal of confusion and misinterpretation regarding the concepts, themes, and goals of education for sustainability. Education for sustainability, including the themes that should be derived and taught, lacks an interdisciplinary conceptual framework. In addition, the literature of education for sustainability mostly lacks the aspects of urban and community planning and the significant contribution of the planning profession. This paper proposes a new conceptual framework, Sustainability Education Framework, which is composed of concepts that derived from different disciplines. At the heart of the conceptual framework rests the normative category and its concepts. The epistemological foundation of the conceptual framework of education for sustainability is based on the unresolved paradox between 'sustainability' and 'development'.
\end{abstract}

Keywords: sustainable development; pedagogy; teaching; theory and practice; urban planning

\section{Introduction}

Education for sustainability is becoming a crucial component in achieving a sustainable life and protecting our planet and human habitats [1-10]. In recent years, we have become increasingly aware of environmental degradation and the significant risks that climate change poses to our cities and communities. Ironically, people themselves, through their economic production and modes of consumption, are major contributors to the environmental crisis. Scholars, practitioners, environmental 
activists, policy makers, teachers and others have been attempting to address the environmental crisis and climate change through a multitude of 'sustainability practices' in general and through education at various levels in particular. It appears that environmental education and education for sustainability have acquired a certain influence over the design of educational and environmental public policies around the world in recent years [11,12]. Education has risen higher on the international and national agendas since the Earth Summit in 1992, which highlighted the role of education in sustainable development [1,2,13,14]. The United Nations General Assembly, through its Resolution 57/254, declared a DESD — Decade of Education for Sustainable Development (2005-2014). It also designated UNESCO as the lead agency for the promotion this important mission at the global level. The DESD suggests that "Education is a motor for change," and it should contribute to enabling citizens to face the challenges of the present and future and leaders to make relevant decisions for a viable world [4]. Importantly, it has obtained significant recognition by international organizations and it becomes a key factor in the world vision of sustainability.

Yet, a review of the sustainability literature reveals a great deal of confusion and misinterpretation regarding the emerging interdisciplinary field of education for sustainability. Some scholars argue that there is a critical need for redefining sustainability education and environmental education [15-18]. Jason MacVaugh and Mike Norton (2012) [19] argue that the development of academic programs about sustainability is inherently problematic. Barraza et al. (2003) [16] suggest that "Environmental education emerged 30 years ago as an urgent alternative to help modify human behavior. Today, there is a need for reorienting and redefining the paths in which environmental education needs to move forward." (2003, p. 348). Saylan and Blumstein (2011, p. 1) [20] argue that "environmental education has failed to bring about the changes in attitude and behavior necessary to stave off the detrimental effects of climate change, biodiversity loss, and environmental degradation that our planet is experiencing at an alarmingly accelerating rate." They argue that environmental education has failed in part because of its limitations. In particular, there are four primary theoretical and practical problems with education for sustainability, which this paper aims to address through proposing a new conceptual framework of education for sustainability. These problems are related to the confusion over the themes, concepts, and goals of education for sustainability. These problems are as follow.

\subsection{Confusion between Environmental Education and Education for Sustainability}

This paper suggests that there is substantial confusion in the literature in the field of environmental education in general, and particularly between environmental education and sustainability education. Environmental education has primarily focused on the relationship between human behavior and nature. Its intent is "to educate the world's citizens about our relationship with Planet Earth." ([10], p. 3). According to the Tbilisi Declaration, one of the seminal documents in environmental education (Intergovernmental Conference on Environmental Education, 1977), the ultimate goal of environmental education is to "make better use of natural resources" in satisfying human needs ([21], p. 13) and "to create new patterns of behavior of individuals, groups and society as a whole towards the environment" ([21], p. 15).

The Tbilisi Declaration came five years after the 1972 Declaration of the United Nations Conference on Human Environment in Stockholm, which asserted that "to defend and improve the 
environment for present and future generations has become an imperative goal for humankind." Environmental education is now widespread in national educational policies around the world [9]. On the other hand, sustainability has emerged as a complex space that incorporates social, political, and ethical issues and not only nature-oriented concerns and environmental anxieties. It is broader in scope and incorporates spatial and economic themes as well as social practice. Its discourses incorporate a variety of theoretical approaches and philosophical currents such as feminism, multiculturalism, democracy, civic engagement and human rights. This paper suggests that education for sustainability differs from environmental education in scope, content, concepts and strategies. These differences make it crucial to distinguish environmental education from sustainability education. Suzana Machado Pádua (2008) [22] examines two terms which have been used as venues in the search for sustainability over the past decades: environmental education and sustainable development. She argues that although their meanings vary, as authors often interpret each one in contrasting ways, both terms emerged from the need to face the crisis caused by modern ways of life. In fact Campbell and Robottom (2008) [23] argue that we are currently in a situation in which 'environmental education' is being aggressively and extensively 're-badged' as 'education for sustainable development'. Yet, they ask, do these rhetorical changes make any difference where it counts - 'on the ground' in classrooms and other educational settings? Moreover, it appears that the strong EE roots of ESD have led to an over-emphasis on the rural dimensions and a failure to really take up and develop the nature of urban ES. Agyeman (1998) [24] argues that teachers in England at Key Stage 2 (KS2), i.e., teachers of pupils of 7-11-years-old, have been influenced by Urban Wildlife Groups (UWGs), amongst others, in relation to what they teach in urban nature, and they have selected ideas from a set of traditional ecological values, theories and practices, originally developed for rural, not urban environments.

\subsection{A Lack of a Conceptual Framework of Education for Sustainability (CFES)}

Sustainable development is a multidisciplinary phenomenon that incorporates various fields of science and knowledge. A salient weakness of the scholarship on sustainability in general, and specifically education for sustainability is the lack of multifaceted theorizing and its tendency to overlook the multidisciplinary and complex nature of sustainability [25]. Therefore, there is a need for CFES that is based on multidisciplinary theoretical foundations. Because sustainability is a multidisciplinary phenomenon, focusing on just one or a few contributing factors ultimately results in partial or inaccurate conclusions and misrepresentation of the multiple causes of the phenomenon examined. For this reason, we need a "paradigm shift" toward transdisciplinary thinking [26]. Scholars and practitioners of urban sustainability face the major theoretical challenge of developing a multidisciplinary theory that integrates social, economic, cultural, environmental, spatial and physical dimensions into a unified conceptual framework for understanding sustainability. Beringer, Maik and Scott ([7], p. 603) argue that: the field is under scrutiny for its lack of theoretical underpinning and theorizing." Apparently, the field lacks a comprehensive theoretical framework that would explain the scope, nature, and assumptions of education for sustainability. Such a theoretical framework is particularly essential because the sustainability practices that have been developed to cope with the 
current environmental crisis challenge the concepts, procedures, strategies, and scope of traditional urban planning theories.

\subsection{Vague Themes of Sustainability Education}

The third issue is related to the themes, or concepts, and goals of education for sustainability. As they appear in the international literature on sustainability, the themes of sustainability education are vague, overly broad and highly variable. Apparently, there is no conceptual framework to organize these themes or concepts of sustainability education under one theoretical roof. Significantly, the engaged themes of sustainability education are related to the three pillars of development: society, environment and economy [1,2]. Yet, a critical category of themes which is related to urban and community planning is mostly neglected. This paper suggests that the urban aspects such as urban forms, energy, infrastructure, management and urban governance are critical issues for sustainability education.

\subsection{Inconsistent Goals of Sustainability Education}

Since there is a lack of such a conceptual framework as a theoretical reference, the goals and objectives of sustainability education are also vague and not consistent as appear in the international literature of sustainability education. According to the Council for Environmental Education ([27], p. 3), the goal of education for sustainable development is to enable "people to develop the knowledge, values and skills to participate in decisions about the way we do things individually and collectively, both globally and locally, that will improve the quality of life now and without damaging the planet for the future" (see [8]). And the goals of education for sustainability according to UNESCO (2008) [2] are to enable people "to free themselves from poverty and to build sustainable livelihoods". Yet, the results are that current education practices have not enabled people to live sustainably thus far; indeed, many would argue that they have actively contributed to unsustainable living, especially in northern or so-called 'developed' countries.

This paper aims to propose a conceptual framework aiming at contributing to reduce the confusing between environmental education and sustainability education, and to reduce the confusion over the concepts and themes of education for sustainability that should be taught in higher education.

\section{The Challenges of Education for Sustainability}

This paper suggests that there are three central challenges that education for sustainability should address.

\subsection{The Multidisciplinary Nature of Sustainability}

Sustainable development is a multidisciplinary phenomenon that poses a challenge for pedagogy in all fields [15]. And sustainable development should not be treated monolithically in the educational system but in a more holistic manner. Cortese (2006) [28] suggests that "designing a sustainable human nature requires a paradigm shift toward a systemic perspective emphasizing interdisciplinary understanding, collaboration, and cooperation that must be led by higher education.” ([28], p. 5). 
Høyer and Naess (2008) [29] suggest that interdisciplinarity has been a significant term in the ecological debate since the early 1960's, and that sustainable development is truly interdisciplinary, including biological, physical, socio-economic, cultural as well as normative contexts and aspects. Moreover, they argue that bridging between different disciplines is crucial in order to be able to conduct cutting-edge inquiry into sustainability issues. Significantly, promoting urban sustainable development should be based on interdisciplinary thinking [29]. Yet, Evans and Marvin (2006) [30] questioned the quality and success of interdisciplinary work in the field of urban sustainability, and concluded that 'interdisciplinarity' remained unaccomplished. Similarly, Høyer and Naess (2008, p. 179) argue that "in spite of the long-time request for interdisciplinarity, the development within the academic world has proceeded in the opposite direction," and that "many of the most influential metatheoretical perspectives virtually prohibit, or at best strongly discourage, the inclusion of insights about certain parts of reality". Moreover, Watson, Wienand, and Workman (2009) ([31], p. 905) found that "different groups of academics, albeit from the same institution, have a variety of interpretations of the concept of sustainability".

Moreover, Education for Sustainable Development involves a comprehensive approach to educational reform and integrating the objectives, concepts and learning experiences of Education for Sustainable Development into syllabuses and teaching programmes is an important part of such reform. It requires the attention of teachers, educational administrators, planners and curriculum agencies [1]. In sum, "a basic premise of education for sustainability is that just as there is a wholeness and interdependence to life in all its forms, so must there be a unity and wholeness to efforts to understand it and ensure its continuation. This calls for both interdisciplinary inquiry and action" ([5], p. 89). Moreover, Segalàs, Mulder, and Ferrer-Balas (2012) [18] emphasize the lack of social and institutional aspects in sustainability courses and they suggest promoting a discussion about how these elements and complex thinking can increase their importance in the curriculum.

\subsection{The Complex and Uncertain Nature of Sustainability}

'Complexity sciences' evolved from ideas associated with dynamic systems - ideas about chaos, nonlinearity, emergence and surprise. In some respects, cities "are in the vanguard of these developments." ([32], p. 1; [33], p. 93). The concept of 'complexity' offers a coherent perspective that organizes our knowledge from many disciplines and that has recently come to the forefront [32]. It is an interdisciplinary field concerned with the study of the general attributes of evolutionary natural and social systems [34]. This approach has placed a particular emphasis on "structural change driven by non-linear dynamics, as well as exploration of the propensity of complex systems to follow unstable and chaotic trajectories," and is increasingly viewed as an important step toward the construction of alternative evolutionary schemas ([34], p. 1). McGlade and Garnsy (2006) ([34], p. 1) suggest that the emergence of alternative ways of representing relationships and the complexity of things has also opened new possibilities in the social sciences, which have been dominated by the search for linear and predictive relationships that require heroic assumptions "that may distort rather than clarify." It acknowledges unpredictability and uncertainty, ambiguity and pluralism, and without being entirely relativist, casts doubt on the certainty of theory and science that has hitherto dominated our thinking about cities ([32], p. 31). 
Sustainability on the urban and city levels is a complex phenomenon: non-linear, uncertain, fundamentally non-deterministic, dynamic in structure, and uncertain in nature. It is affected by a multiplicity of economic, social, spatial, and physical factors. Sustainability planning involves a wide range of stakeholders, including civil society, local and national governments, the private sector, and various professional communities, and it affects a variety of urban communities and city residents. By nature, working on urban sustainability requires complex thinking and complex methods. It also forces us to adopt a more holistic view [32]. Apparently, learning is "about change: the change brought about by developing a new skill, understanding something new, changing an attitude is a relatively permanent change, usually brought about intentionally and purposefully." ([35], p. 59, quoted in [36]) This strategy encourages the motivation of the students to learn through their project outcomes and design [35].

Education for sustainability is also related to complexity and uncertainty. It deals with the complex amalgamation of issues relevant to environment, society, politics, and economy [3,18,37,38]. Yet, "environmental education has failed to bring about the changes in attitude and behavior necessary to stave off the detrimental effects of climate change, biodiversity loss, and environmental degradation that our planet is experiencing at an alarmingly accelerating rate" ([20], p. 3). They argue that environmental education has failed in part because of its limitations. Therefore, they suggest that environmental education must teach people not only about their physical environment but also how to live and flourish in sustainable ways. Importantly, they suggest that we must incorporate complexity and encompass multidisciplinary teaching approaches. They argue for "one that stimulates community engagement, fosters an understanding of moral systems, and reinforces the appreciation of aesthetics" ([20], p. 3).

\section{The Methods of Building the Sustainability Education Framework}

Elsewhere, I developed a grounded qualitative method for building conceptual frameworks in social sciences [39,31]. Accordingly, in my theorization of education for sustainability, I adopt the ontological conceptualization of planes of immanence and the term concept as used by Deleuze and Guattari (1991) [40]. My aim is to build a conceptual framework for Sustainability Education Framework (SEF). The conceptual framework for $S E F$ is a plane of immanence that is "an object of construction," ([41], pp. 62-63). In philosophical terminology, immanence refers to "the act of being within a conceptual space." ([41], p. 98). In this manner, Sustainability Education Framework refers to a network, or 'a plane,' of interlinked concepts that together provide a comprehensive understanding of a phenomenon. This plane is composed of concepts that "can be abstracted from bodies and states of affairs." ([41], p. 31). A conceptual framework, however, is not merely a collection of concepts but rather a construct composed of 'consistent' concepts in which each plays an integral role and is intrinsically linked to the others. This enables it to better provide "not a causal/analytical setting but, rather, an interpretative approach to social reality" and to our understanding of the multiple and interlinked concepts it encompasses ([39], p. 51).

The Definition of 'Concept': According to Deleuze and Guattari (1991) [40], "every concept has components and is defined by them" and "there is no concept with only one component" (p. 15). These components define the consistency of the concept and are distinct, heterogeneous, and 
inseparable from one another (p. 19). It is a multiplicity, but not every multiplicity defines a concept. Every concept must be understood "relative to its own components, to other concepts, to the plane on which it is defined and to the problem it is supposed to resolve" (p. 21). Moreover, every concept has its own history and typically contains 'bits' or components originating from other concepts. In other words, all concepts relate back to other concepts; they are always created from something, and cannot be created from nothing.

Accordingly, I use a conceptual analysis method to build the conceptual framework. This method is a grounded theory technique that aims "to generate, identify, and trace a phenomenon's major concepts, which together constitute its theoretical framework." [39]. Each concept possesses its own attributes, characteristics, assumptions, limitations, distinct perspectives, and specific function within the conceptual framework. The methodology delineates the following stages in conceptual framework building: (a) mapping selected data sources; (b) reviewing the literature and categorizing the selected data; (c) identifying and naming the concepts; (d) deconstructing and categorizing the concepts; (e) integrating the concepts; (f) synthesis, resynthesis, and making it all make sense; (g) validating the conceptual framework; and (h) rethinking the conceptual framework. The construction of the Sustainability Education Framework and identification of the major concepts of sustainability were generated through qualitative process analysis based on grounded theory method, which involves the extensive review and classification of the literature addressing environmental, social, cultural, and urban aspects of sustainability in a variety of disciplines and fields of study, such as sociology, anthropology, public policy, political science, economics, ecology, geography, and urban planning. This broad, multidisciplinary framework is intended to ensure that the theory generated is relevant to as many disciplines as possible, enabling them to expand the respective theoretical perspectives with which they approach the phenomenon [39].

\section{The Concepts of the Sustainability Education Framework}

The Sustainability Education Framework incorporates five interrelated categories while each category includes one or more concepts as follows.

\subsection{The Normative Category}

At the heart of the conceptual framework rests the normative category and its concepts as seen in Figure 1. This category includes four interrelated concepts: the ethical paradox of sustainability, the vision, the equity, and the politics. This central category suggests that the epistemological foundation of the conceptual framework of education for sustainability is based on the unresolved and fluid paradox of sustainability, which exists between 'sustainability' and 'development'. The concept of ethical paradox suggests that on the other hand, however, development is an environmental modification that requires intervention in nature and exhausts natural resources. The other three concepts of this category, the vision, equity, and politics represent various, crucial, and critical themes of normative aspects and justice regarding sustainability as will see in the following sections. 
Figure 1. The Conceptual Framework of Education for Sustainability: Categories and their Concepts.

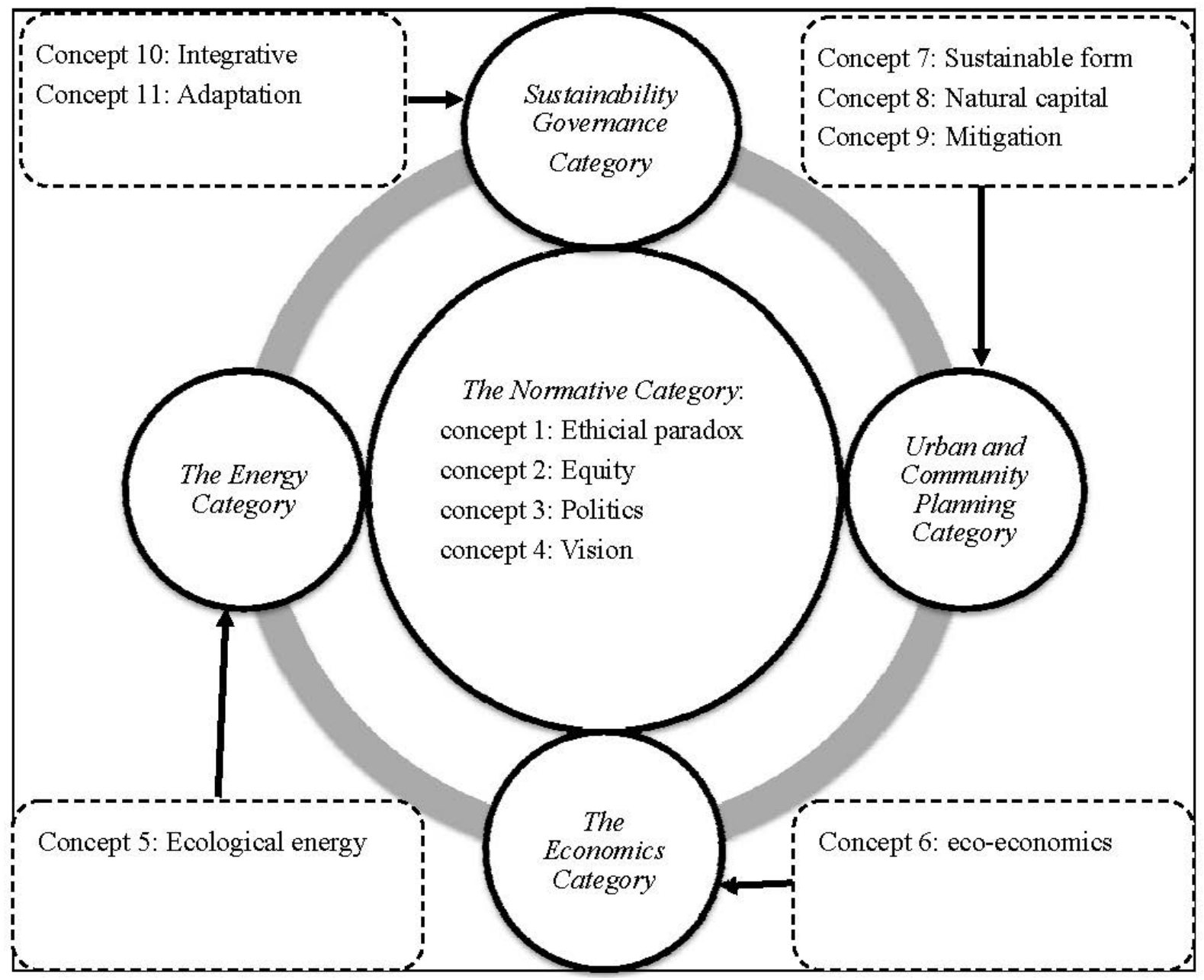

\subsubsection{The Ethical Paradox}

This concept represents the paradox between 'development' and 'sustainability' and implicitly evaluates the levels of the plan for intervention on natural capital, such as lands, air, and water. This paradox is represented in the most frequently used definition of sustainable development: that of Brundtland Report, which deemphasizes the environment while underlining human needs to be realized through development. 'Sustainable development' aims to mitigate and moderate between the paradox between ecological sustainability and economic development. Sustainable development is accordingly deemed defined by the Brundtland Commission, is instructive: "Development involves a progressive transformation of economy and society". Yet, many scholars question the ethics behind the concept and suggest that it is ethically hollow [42].

Apparently, this concept illuminates the intervention levels of humans, the economic development and interventional projects on natural assets. Eventually, the paradoxical and dialectical relations between sustainability and development tolerate diverse interpretations and practices that are related to a varied spectrum of ideologies. It ranges between two extreme: the 'domination of nature' and the 'intrinsic right of nature.' The former is represented by doctrine of 'light ecology' and the latter by 
doctrines of 'deep ecology'. Between these concepts lie many approaches, which attempt to reconcile this paradox and to address the dialectical relations between development and sustainability [42].

\subsubsection{Equity}

The concept of equity represents the normative social aspects of sustainability, and it analyzes the environmental, economic and social justice of the plan, including its procedural justice in terms of public participation. Agyeman (2005) [43] suggests that there should be a shift in redefining sustainability to include social justice and various urban issues such as urban disinvestment, racism, homes, jobs, neighborhoods alongside natural resources and pollution. A more equitable distribution of power and resources contributes to improvement in environmental quality and reduces injustice, whereas a greater power inequality leads to greater environmental degradation [44-47]. The impacts of climate change and its mitigation policies are "socially differentiated" and are a matter of distributional equity and justice both locally and internationally [48-50].

Climate change has already led to changes in ecological, spatial, and socio-economic systems. Importantly, there are individuals and groups within all societies that have insufficient capacity to adapt to climate change. "Vulnerability to climate change refers to the propensity of human and ecological systems to suffer harm and their ability to respond to stresses imposed as a result of climate change effects." IPCC (2007, p. 720) [51]. Notably, the vulnerability of a society is influenced by its development path, physical exposures, the distribution of resources, prior stresses, social networks, government institutions, and technology IPCC (2007, p. 719-720) [51]. Communities have different vulnerabilities within each country [49].

\subsubsection{The Utopian Vision of Sustainability}

This concept represents the normative agenda of human actions in the future. It reframes the human vision toward a more sustainable future. The power of utopian thinking is its inherent ability to see the future in terms of radically new forms and values [52]. This framing is critical for achieving sustainability objectives in general and in sustainability education in particular. This concept demonstrates the visionary aspects of economic development and planning regarding the discourse of future urban life and the contribution of the city to climate change adaptation efforts. The utopian concept envisages human cities and communities based generally on a better life and mitigation of the environmental crisis. Moreover, It represents the urban utopia of the plan and it's framing discourse and asks what alternative ecological urban visionary picture the plan suggests for the city [53].

Education is a central part of recent human visions to the future based on the concept of sustainability. Visions and values of sustainability are significant for education for sustainability (see [6]). The UN Decade of Education for Sustainable Development, (2005, p. 4) [4] suggests an ideal to the humanity, which proposes "to be respectful of the Earth and life in all its diversity, and be committed to promoting democracy in a society without exclusion and where peace prevails". This vision of the world could be achieved also through "taking into account education in sustainable development plans, creating public awareness of the importance of sustainable development, having regular and substantial coverage of sustainable development issues in the media". Neal and 
Palmer (1994, p. 3) [54] suggest that no environmental education program "can be successful without individual commitment and personal concern."

\subsubsection{Politics}

This concept is about the normative aspects of politics regarding sustainability and its discourse and practices. It is also about the local and global politics of sustainability. It presents the idea of a global agenda, or our 'all agenda', as an emerging new worldwide political discourse reconstituted around the ideas of sustainability. Since the Rio Summit, this discourse has extended beyond purely ecological concepts to include various international issues, such as security, peace, trade, heritage, hunger, shelter, and other basic services. Simultaneously, this concept reflects deep political disputes among various countries, such as developed and developing countries, which undermine the achievability of sustainability.

\subsection{The Sustainability Governance Category}

This category is about the governance and management of social and economic human practices that are directed towards achieving sustainability at the short and long run. It includes four interrelated concepts that focus on adaptation and uncertainty management, energy, economics and management aspects of governance.

\subsubsection{Adaptation and Uncertainty Management}

This concept is about adaptation management and risk management (see [31]). Adaptation is defined as an "adjustment of behavior to limit harm, or exploit beneficial opportunities, arising from climate change" ([55], p. 60). Most cities and countries appear to be applying mitigation policies to address the human causes of climate change by reducing greenhouse gas emissions, but have failed to apply adaptation policies as well. The CCC (2010) suggests that "even with strong international action on mitigation, past and present emissions mean that the climate will continue to change" ([55], p. 60). In this way, adaptation and mitigation are not alternatives; rather, they are complementary.

Recent evidence indicates that climate change is accelerating and will lead to wide-ranging shifts in climate parameters, and it "poses novel risks often outside the range of experience, such as impacts related to drought, heat waves, accelerated glacier retreat and hurricane intensity" ([51], p. 719). Eventually, climate change creates new uncertainties. "Uncertainty is a perceived lack of knowledge, by an individual or group, which is relevant to the purpose or action being undertaken and its outcomes." [56]. Environmental uncertainty arises from the changing social, economic, and physical environment and is experienced by everyone. External uncertainties arise from the external environment [56] and relate to external processes and events which may affect the planning process and the urban environment being planned.

The challenge is to be more aware of the new and unconventional uncertainties, brought about by climate change, which pose a new challenge to humanity. Apparently we need a better understanding of the risks facing communities, households, and urban physical infrastructure; the potential impacts on household well-being and social outcomes; and how to effectively lower community, household, 
and urban vulnerability [48,57-61]. In this case, there are two types of uncertainty management, adaptation management, or risk management: (1) Ex-ante management, which includes prevention or risk reduction, actions to reduce the probability of risky events (e.g., emissions reductions); (2) Ex-post management, which includes risk coping, actions taken to make up for losses after realization of a risky event [62].

\subsubsection{The Integrative Concept}

The integration of environmental, social, and economic concerns in planning and holistic management approaches is essential for achieving sustainability. The integrative approach seeks to unite all stakeholders: civil society organizations, communities, and various social groups. Addressing the risk associated with climate change generally requires dealing with scenario uncertainty. "The ability of a governance system to adapt to uncertain and unpredicted conditions is a new notion" ([38], p. 152). Adaptive management is undertaken in conditions with a high level of uncertainty, seeks to integrate uncertainties into the planning process, and ought to meet stakeholders' expectations in an uncertain environment. Therefore, adaptive management requires new planning strategies and procedures beyond conventional planning approaches. "Adaptive governance needs to be investigated at a number of levels and dimensions, for instance at policy level, planning level, implementation, administration, etc. Strategists need to design plans that not only address the environmental, economic and social needs today but also plans that are flexible enough to quickly adapt to our rapidly changing environment" ([38], p. 152).

\subsection{The Energy Category}

This category includes one concept.

\section{Ecological Energy}

The clean, renewable, and efficient use of energy is a central theme in planning to achieve climate change objectives. This theme addresses the energy sector and whether it proposes strategies to reduce energy consumption and to use new, alternative, and clean energy sources. This concept evaluates how the plan addresses a major and fundamental condition for sustainability.

\subsection{The Economics Category}

This category includes one concept.

\section{The Ecological Economics Theme}

This theme assumes that environmentally sound economics could be a decisive driving force for achieving sustainability in a capitalist world. For example, it appears that President Barack Obama is trying to combat a recession and job losses with a huge ramp-up in green-energy spending [61]. Obama's goal is to generate new jobs while simultaneously transforming the energy marketplace, heading off global warming, and building a U.S. clean-energy economy and industry. His energy spending marks a sharp departure from the past 25 years, both in quantity and focus. 
Climate-change legislation is a central tenant of his program. A "market-based cap on carbon pollution" would drive the production of more renewable energy in America, he said. He promised to invest $\$ 15$ billion annually for 10 years to support energy innovation leading to new technologies such as "wind power and solar power, advanced bio-fuels, clean coal, and more fuel-efficient cars and trucks built right here in America". Moreover, "the American Recovery and Reinvestment Plan signed by the President will spur job creation while making long-term investments in energy, and infrastructure. Among other objectives, the recovery plan will increase production of alternative energy". Obama said that in order "to truly transform our economy, protect our security, and save our planet from the ravages of climate change, we need to ultimately make clean, renewable energy the profitable kind of energy" [61].

\subsection{Urban and Community Planning}

This category includes three concepts and it represents the urban and community aspects of spatial, social, and economic planning as follows.

\subsubsection{The Natural Capital}

Natural capital represents the natural assets that we need to protect and improve. Natural capital is "the stock of all environmental and natural resource assets, from oil in the ground to the quality of soil and groundwater, from the stock of fish in the ocean to the capacity of the globe to recycle and absorb carbon" [62]. Natural capital represents the consumption level of the environmental and natural resource assets that are used for development. Keeping natural capital constant is an important criterion for sustainability. Pearce and Turner ([63], p. 44) note that "the resource stock should be held constant over time." The stock of natural capital should not decrease so that the opportunities of future generations to generate wealth and well-being are not endangered and the ecological system is not harmed.

\subsubsection{Mitigation}

Countering climate change requires two types of responses: mitigation measures, which aim at reducing greenhouse gas emissions (GHG), and adaptation measures, to deal with the unavoidable effects [64]. According to Bulkeley $(2010,2.2)$ [65], mitigation refers to an "action to reduce the sources (or enhance the sinks) of factors causing climate change, such as greenhouse gases" ([55], p. 61), and to "the reduction of GHG emissions and their capture and storage in order to limit the extent of climate change." The EU has recently agreed to reduce emissions to $20 \%$ below 1990 levels by 2020. However, the agreement could potentially be amended to deliver a $30 \%$ reduction, if undertaken as part of an international agreement in which other developed countries agree to comparable reductions and appropriate contributions by more economically advanced developing countries. The Commission of the European Communities (CEC) (2009) [64] suggests that "even if the world succeeds in limiting and then reducing GHG emissions, our planet will take time to recover from the greenhouse gases already in the atmosphere. Thus we will be faced with the impact of climate change for at least the next 50 years. We need therefore to take measures to adapt." 


\subsubsection{The Sustainable Form}

This concept evaluates the aspects of spatial planning, architecture, design, and ecologically desired form of the city and its communities. The physical form of city affects habitat, ecosystem, daily-life activities and spatial practices of inhabitants, and eventually the response to climate change. Contemporary urban form has been perceived as a source of environmental problems [66-71]. In a previous study I suggest $[68,72]$ a distinctive set of seven concepts by which human habitat can be classified in terms of their "environmental burden" and develop a Sustainable Urban Form Matrix that contributes to our evaluation of the sustainability of a given form. The study concludes that, by using the right scale of the proposed concepts, we may produce the most sustainable urban forms that contribute to the climate change adaptation strategies. The ideal sustainable urban form according to these concepts is that which has a high density and adequate diversity, is compact with mixed land-uses, and has a design is based on sustainable transportation, greening and passive solar energy. The concept of Urban Form Matrices is composed of seven criteria as follows:

a. Compactness: Compactness refers to urban contiguity and connectivity and suggests that future urban development should take place adjacent to existing urban structures [73]. Compactness of urban space can minimize transport of energy, water, materials, products, and people [74]. Intensification, a major strategy for achieving compactness, uses urban land more efficiently by increasing the density of development and activity. It includes: development of previously undeveloped urban land; redevelopment of existing buildings or previously developed sites; subdivisions and conversions; and additions and extensions [75].

b. Sustainable Transport: To achieve sustainable transportation goals ST the plan should address the following criteria: shorter trips; less traffic; encouragement of non-motorized travel such as walking and cycling; safety; transit-oriented development; minimal use of land; equitable access for people and their goods in each generation; and the plan should be powered by renewable energy sources [71,76-78].

c. Density: Density is the ratio of people or dwelling units to land area. Density affects climate change through differences in the consumption of energy, materials, and land for housing, transportation, and urban infrastructure. High density can save significant amounts of energy.

d. Mixed Land Uses: Mixed land use indicates the diversity of functional land uses such as residential, commercial, industrial, institutional, and transportation. It allows compatible land uses to locate in close proximity to one another and thereby decreases the travel distances between activities, encourages walking and cycling, and reduces the probability of using a car for commuting, shopping, and leisure trips because jobs, shops, and leisure facilities are located nearby $[68,79]$.

e. Diversity: Diversity is "a multidimensional phenomenon" that promotes additional desirable urban features, including greater variety of housing types, building densities, household sizes, ages, cultures, and incomes $[80,81,82]$. Diversity is vital for cities and without it the urban system declines as a living place [76] and then homogeneity of built forms, which often produces unattractive, monotonous urban landscapes, leads to increased segregation, driving, congestion, and air pollution [77]. 
f. Passive Solar Design: The idea of solar design is to reduce the demand for energy and to provide the best use of passive energy through specific planning and design measures such as siting, orientation, layout, and landscaping. This can make the optimum use of solar gain and microclimatic conditions, and minimize the need for heating or cooling buildings with conventional energy sources [67,83,84]. Yannis ([85], p. 43) summarizes some design parameters for improving urban microclimate: (a) Built form-density and type, to influence airflow, view of sun and sky, and exposed surface area; (b) Street canyon - width-to-height ratio and orientation, to influence warming and cooling processes, thermal and visual comfort conditions, and pollution dispersal; (c) Building design - to influence building heat gains and losses; (d) Urban materials and surfaces finish - to influence absorption, heat storage, and emissivity; (e) Vegetation and bodies of water - to influence evaporative cooling processes on building surfaces and/or in open spaces; and (f) Traffic-reduction, diversion, and rerouting to reduce air and noise pollution and heat discharge.

g. Greening: Greening the city contributes positively to climate change. It aims to bring nature into the city and has many benefits. It maintains biodiversity, ameliorates the physical urban environment, moderates the urban climate; increases the economic attractiveness of a city; fosters community pride; contributes to health and to education; and functions as a symbol or representation of nature $[37,61,86-88]$.

\section{The Strategy for Sustainability Education}

In brief, the proposed strategy addresses three major issues: how sustainability should be taught; what should be taught; and how it should be taught (see [31]).

\subsection{How It Should Be Taught: Theory and Practice}

Sustainability has two interrelated dimensions: theory and practice. Importantly, the theories of sustainability are inspired by practice and the theories in turn inform and inspire practice. Therefore, the curriculum should include both dimensions to ensure that various aspects of sustainability are addressed. Students should acquire theoretical foundations in order to understand and assess practice. In addition, they should learn practice in order to comprehend sustainability theories and implement plans based on those theories. UNESCO (2008) suggests that a common aim of education initiatives should be clearly to relate practice more closely to theory. Generally, the aim of sustainability teaching is to acquire various skills, critical and creative thinking, communication, conflict management and problem solving strategies, project assessment to the students and participants [3].

\subsection{The Way It Should Be Taught}

I suggest three inclusive and complementary active-learning methods to teach sustainability, based on my four years of teaching undergraduate and graduate students in various disciplines, mainly urban planning, architecture, landscape planning, transportation engineering, and environmental studies. 'Active-learning' requires “the educator to privilege the learner's participation over his or her own declarative knowledge of the subject ([19], p. 74). Significantly, active learning may address the 
legitimacy and practicability issues inherent in introducing education for sustainability into various disciplines and academic programs [19]. Active learning is also a 'problem-based learning' (see [37]) methods that contribute to the theory-practice knowledge of students.

\subsubsection{Team Project Strategy}

Sustainability education should have practical aspects such as having student teams completing a project during the semester. David Orr (2006) [89] suggests that teaching sustainability should make learning an active engagement with the world, not merely the study of second-hand abstractions. Therefore, students ought to understand major environmental and un-sustainable actions and policies in their daily surroundings: campus, neighborhood, communities, cities, region or country.

\subsubsection{Individual Action Research: An Individual Practical Assignment}

This assignment aims to expose each student to his/her immediate world, neighborhood, town or city, community, street, building etc. This is an important fieldwork or 'Streetwork' [90] experience and perspectives that contribute to the building of environmental and sustainability awareness. This individual experience is based on action research that contributes to make the link between theory and practice. Reason and Bradbury (2001, p. 1) [91] define action research as "a participatory, democratic process concerned with developing practical knowing in the pursuit of worth-while human purposes, grounded in a participatory world view" and which "seeks to bring together action and reflection, theory and practice, in participation with others, in the pursuit of practical solutions to issues of pressing concern to people, and more generally the flourishing of individual persons and their communities." Reason and Bradbury (2001, p. 2) [91] suggest that the main purposes of action research are: To produce practical knowledge that is useful to people in the everyday conduct of their lives; to contribute through this knowledge to increased well-being-economic, political, psychological, spiritual — of individuals and communities and to a more equitable and sustainable relationship with wider ecology of the planet; and to combine practical outcomes with new understanding (see [92]).

\subsubsection{Workshops}

Workshops are essentially seminars focused on a practical activity. For example, engineering students may work as a group on a practical problem, drama students may work on a performance, or education students may work on a role-play activity about teaching. As with seminars, all students will be expected to participate and to take their turn in leading. These workshops are in fact practical classes, which are important part in developing practical skills and critical for making sense of the theory they learn in class. 


\subsection{What Is to Be Taught: The Themes}

The themes that should be taught should be derived and based on theoretical foundations or in a unified conceptual framework of sustainability. Here, I proposed a conceptual framework of sustainability, which has been developed through an extensive interdisciplinary literature of sustainability. It is composed of concepts that together form a unified theory of sustainability. Previous study of the author [15] suggests seven concepts that together assemble the theoretical framework of 'sustainable development' and each concept represents distinctive meanings of the theoretical framework. Each concept represents distinctive meanings and aspects of the theoretical foundations of sustainability.

\section{Conclusions}

This paper assumes that there is a great deal of confusion and misinterpretation regarding the themes, concept, and goals of education for sustainability. Therefore, it proposes a new conceptual framework, Sustainability Education Framework, which aims to reduce the confusing between environmental education and sustainability education, and the confusion over the concepts and themes of education for sustainability that should be taught in higher education. The main features of this framework are as follows:

a. Sustainability Education Framework is composed of five categories. Each category includes one or more concepts. These categories and their concepts together provide a holistic and interdisciplinary understanding of sustainability. The concepts are derived from different disciplines, and they demonstrate the contribution of various disciplines in general and the urban planning profession in particular. Importantly, at the heart of the conceptual framework rests the normative category and its concepts. This framework suggests that the epistemological foundation of the conceptual framework of education for sustainability is based on the unresolved and fluid paradox of sustainability, which as such can simultaneously inhabit different and contradictory environmental ideologies and practices. The paradox between 'sustainability' and 'development' is articulated in terms of human norms and ethics [42]. Eventually, the paradoxical relations between sustainability and development tolerate diverse interpretations that are related to a varied spectrum of ideologies and practices. It ranges between two extreme: the 'domination of nature' and the 'intrinsic right of nature' [42].

$b$. This framework consists of various categories and themes, and each one represents a specific domain that is related to sustainability. Apparently, the framework represents ethical, social, economic, ecological, spatial, design, and political aspects of sustainability. In other words, the conceptual framework 'tells the story' of sustainable development theories and practices. Importantly, each category and its concepts represent more than one discipline and mostly more than one field of knowledge. Moreover, each category and its concepts have their specific contribution to achieving sustainability in general. And, each has its contribution to the education for sustainability. Yet, these concepts together have the strength to illuminate the sustainability through various disciplines and lenses. 
c. The concepts of eco-form, natural capital, vision, equity, uncertainty governance, and integrative approach are also planning-oriented concepts and they are interlinked. They represent the planning profession and its subdivisions such as spatial planning, economic planning, environmental planning, visioning, procedural, and participatory planning. Education for sustainable development consequently promotes competencies such as critical thinking, imagining future planning scenarios and making decisions in a collaborative way.

d. Following UNESCO 2012 [1], this paper also suggests that education for sustainable development requires far-reaching changes in the way education is often practiced today in terms of themes, concepts and methods. Eventually, education for sustainable development should allow "every human being to acquire the knowledge, skills, attitudes and values necessary to shape a sustainable future" [1]. It means including key sustainable development issues in both teaching and learning. This requires addressing the interdisciplinary aspects of sustainability, promoting participatory teaching and learning methods that motivate and empower learners to change their behavior and take action for sustainable development. Moreover, However, it must be remembered that education and learning are part of the iterative dynamic of social change: in order to change society, we need to change the way we learn and educate, and in order to change the way we learn and educate we need to change society" [2].

e. The proposed conceptual framework addresses the lack of scholarship on sustainability in general and of education for sustainability, in particular. In addition, it addresses the multidisciplinary and complex nature of sustainability and identifies the themes or concepts that should be taught. It appears that scholars operate within a peer group that is self-referential and therefore changes too slowly. This is to look at education as itself a system that is embedded in a particular economic and political power structure.

$f$. The conceptual framework with its ten themes could be used to assess public policies and projects from a sustainability perspective $[93,94]$.

g. Each discipline could take advantage of this framework and emphasize is pertinent aspects accordingly (see $[93,94])$.

$h$. Projects in real world problems and 'problem-based learning' are highly recommended in teaching sustainability through the use of the proposed conceptual framework.

$i$. This paper suggests that education for sustainability is considerably different in scope, content, concepts and strategies from environmental education.

\section{References}

1. United Nations Educational, Scientific and Cultural Organization (UNESCO). Sustainable Future Across the Curriculum. Available online: http://www.unesco.org/education/tlsf/mods/ theme_b/mod06.html (accessed on 6 August 2012).

2. United Nations Educational, Scientific and Cultural Organization (UNESCO). EFA-ESD Dialogue: Educating for a Sustainable World; Education for Sustainable Development Policy Dialogue No.1; UNESCO: Paris, France, 2008. 
3. United Nations Educational, Scientific and Cultural Organization (UNESCO). The UN Decade of Education for Sustainable Development (DESD 2005-2014) The First Two Years. Available online: http://unesdoc.unesco.org/images/0015/001540/154093e.pdf (accessed on 4 April 2007).

4. United Nations Educational, Scientific and Cultural Organization (UNESCO). UN Decade of Education for Sustainable Development. 2005. Available online: http://unesdoc.unesco.org/ images/0014/001416/141629e.pdf (accessed on 28 August 2005).

5. United Nations Educational, Scientific and Cultural Organization (UNESCO). Educating for $a$ Sustainable Future: A Transdisciplinary Vision for Concerted Action; UNESCO: Paris, France, 1997.

6. Kevin, J.K.; Newport, D.; White, J.; Townsend, A.R. Higher education's sustainability imperative: How to practically respond? Int. J. Sustain. High. Educ. 2012, 13, 19-33.

7. Beringer, A.; Maik, A.; Scott, W. Editorial. Environ. Educ. Res. 2008, 14, 603-606.

8. Summers, M.; Corney, G.; Childs, A. Teaching sustainable development in primary schools: An empirical study of issues for teachers. Environ. Educ. Res. 2003, 9, 327-346.

9. Rickinson, M. Learners and learning in environmental education: A critical review of the evidence. Environ. Educ. Res. 2001, 7, 207-320.

10. Palmer, J. Environmental Education in the 21st Century: Theory, Practice, Progress and Promise; Routledge: New York, NY, USA, 1998.

11. González-Gaudiano, E.; Peters, M.A. Environmental Education: Identity, Politics and Citizenship; Sense: Rotterdam, The Netherlands, 2008; pp. 1-11.

12. Mochizuki, Y.; Fadeeva, Z. Regional centres of expertise on education for sustainable development (RCEs): An overview. Int. J. Sustain. High. Educ. 2008, 9, 369-381.

13. Middle East Studies Association (MESA). Mainstreaming Environment and Sustainability across Africa. In Proceedings of the Conference Nairobi, Nairobi, Kenya, 17 November 2010. Available online: http://www.unep.org/training/downloads/MESA-Tongji\%20meeting\%20programme.pdf (accessed on 17 April 2012).

14. Asia/Pacific Cultural Centre for UNESCO (ACCU). ESD Journey of HOPE-Holistic Ownership Priorities Empowering. Final Report of the Asia-Pacific Forum for ESD Educators and Facilitators; ACCU: Tokyo, Japan, 2010.

15. Jabareen, Y. Teaching sustainability: A multidisciplinary approach. Creat. Educ. 2011, 2, 388-392.

16. Barraza, L.; Duque-Aristiza, B.A.M.; Rebolledo, G. Environmental education: From policy to practice. Environ. Educ. Res. 2003, 9, 347-357.

17. Nagata, Y. Tales of Hope II Innovative Grassroots Approaches to ESD in Asia and the Pacific ACCU Japan; Asia/Pacific Cultural Centre for UNESCO (ACCU): Tokyo, Japan, 2009.

18. Segalàs, J.; Mulder, K.F.; Ferrer-Balas, D. What do EESD “experts" think sustainability is? Which pedagogy is suitable to learn it? Results from interviews and Cmaps analysis gathered at EESD 2008. Int. J. Sustain. High. Educ. 2012, 13, 293-304.

19. MacVaugh, J.; Mike, N. Introducing sustainability into business education contexts using active learning. Int. J. Sustain. High. Educ. 2012, 13, 72-87.

20. Saylan, C.; Blumstein, D.T. The Failure of Environmental Education: And How We Can Fix It; University of California Press: Berkeley, CA, USA, 2011. 
21. UNESCO and UNEP. Intergovernmental Conference on Environmental Education. Available online: http://unesdoc.unesco.org/images/0003/000327/032763eo.pdf (accessed on 22 August 1997).

22. Machado Pádua, S. The Combination of Environmental Education and Sustainable Development for Community Programs: A Case Study by IPE in Brazil. In Environmental Education: Identity, Politics and Citizenship; González-Gaudiano, E., Peters, M.A., Eds.; Sense: Rotterdam, The Netherlands, 2008; pp. 249-258.

23. Campbell, C.; Robottom, I. What's in a Name? Environmental Education and Education for Sustainable Development as Slogans. In Environmental Education: Identity, Politics and Citizenship; González-Gaudiano, E.; Peters, M.A., Eds.; Sense: Rotterdam, The Netherlands, 2008; pp. 195-206.

24. Agyeman, J. Teaching urban nature at key stage 2 in England: Looking at what is there, not at what ecologists say should be there. Environ. Educ. Res. 1998, 4, 139-154.

25. Timpson, W.M.; Dunbar, B.; Kimmel, G.; Bruyere, B.; Vewman, P.I.; Mizia, H. 147 Practical Tips for Teaching Sustainability: Connecting the Environment, the Economy, and Society; Atwood Publishing: Madison, WI, USA, 2006.

26. Bosher, L.S. Hazards and the Built Environment: Attaining Built-In Resilience; Taylor and Francis: London, UK, 2008.

27. Consortium for Energy Efficiency (CEE). Education for Sustainable Development in the Schools Sector: A Report to DfEE/QCA from the Panel for Education for Sustainable Development (Reading, Council for Environmental Education); CEE: Boston, MA, USA, 1998.

28. Cortese, A. Higher Education and Sustainability. In 147 Practical Tips for Teaching Sustainability: Connecting the Environment, the Economy, and Society; Timpson, W.M., Dunbar, B., Kimmel, G., Bruyere, B., Vewman, P.I., Mizia, H., Eds.; Atwood Publishing: Madison, WI, USA, 2006; p. 5.

29. Høyer, K.G.; Naess, P. Interdisciplinarity, ecology and scientific theory: The case of sustainable urban development. J. Crit. Realism 2008, 7, 179-207.

30. Evans, R.; Marvin, S. Researching the sustainable city: Three modes of interdisciplinarity. Environ. Plan. A 2006, 38, 1009-1028.

31. Watson, P.; Wienand, N.; Workman, G. Teaching sustainability: A valid methodology for addressing the associated problematic issues. World Acad. Sci. Eng. Technol. 2009, 29, 902-906. Available online: http://www.waset.org/journals/waset/v29/v29-148.pdf (accessed on 15 April 2009).

32. Batty, M. Complexity in City Systems: Understanding, Evolution, and Design; MIT Press: Cambridge, MA, USA, 2007.

33. Marc, B.; de Roo, G. What Can Spatial Planning Learn from Ecological Management? Exploring Potentials of Panarchy for Spatial Management. In Book of Abstracts: 24th AESOP Annual Conference; Aalto University: Aalto, Finland, 2010; pp. 93-94.

34. McGlade, J.; Garnsy, E. The Nature of Complexity. In Complexity and Co-Evolution; Garnsey, E., McGlade, J., Eds.; Edward Elgar: Northampton, MA, USA, 2006; pp. 1-21.

35. Reece, I.; Walker, S. Teaching, Training and Learning, 5th ed.; Business Education Publishers Limited: Sunderland, UK, 2003. 
36. McDermott, R.P.J.; Lynda, M.H.; Alan Strong, W. Reflections on trailing two teaching strategies for sustainability management education in an undergraduate engineering module. In Proceeding of 3rd International Symposium for Engineering Education, University College Cork, Ireland, 1-2 July 2010. Available online: http://www.ucc.ie/ucc/depts/foodeng/isee2010/ pdfs/Papers/McDermott\%20et\%20al.pdf (accessed on 11 August 2012).

37. Dobson, H.E.; Bland Tomkinson, C. Creating sustainable development change agents through problem-based learning: Designing appropriate student PBL projects. Int. J. Sustain. High. Educ. 2012, 13, 263-278.

38. Mirfenderesk, H.; Crokill, D. The need for adaptive strategic planning sustainable management of risks associated with climate change. Int. J. Clim. Change Strateg. Manag. 2009, 1, 146-159.

39. Jabareen, Y. Building conceptual framework: Philosophy, definitions and procedure. Int. J. Qual. Methods 2009, 8, 49-62.

40. Deleuze, G.; Guattari, F. What is Philosophy?; Columbia University Press: New York, NY, USA, 1991.

41. Mark, B.; Protevi, J. Deleuze and Geophilosophy: A Guide and Glossary; Edinburgh University Press: Edinburgh, UK, 2004.

42. Jabareen, Y. A new conceptual framework for sustainable development. Environ. Dev. Sustain. 2008, 10, 197-192.

43. Agyeman, J. Sustainable Communities and the Challenge of Environmental Justice; New York University Press: New York, NY, USA, 2005.

44. Agyeman, J.; Bullard, R.D.; Evans, B. Exploring the nexus: Bringing together sustainability, environmental justice and equity. Space Polity 2002, 6, 77-90.

45. Boyce, J.K.; Klemer, A.R.; Templet, P.H.; Willis, C.E. Power distribution, the environment, and public health: A state-level analysis. Ecol. Econ. 1999, 29, 127-140.

46. Solow, R.M. Sustainability: An Economist's Perspective; The Eighteenth J. Seward Johnson Lecture. Woods Hole Oceanographic Institution: Woods Hole, MA, USA, 1991.

47. Stymne, S.; Jackson, T. Intra-generational equity and sustainable welfare: A time series analysis for the UK and Sweden. Ecol. Econ. 2000, 33, 219-236.

48. Adger, W.N.; Agrawala, S.; Mirza, M.M.Q.; Conde, C.; O’Brien, K.; Pulhin, J.; Pulwarty, R.; Smit, B.; Takahashi, K. Assessment of Adaptation Practices, Options, Constraints and Capacity. In Climate Change 2007: Impacts, Adaptation and Vulnerability. Contribution of Working Group II to the Fourth Assessment Report of the Intergovernmental Panel on Climate Change; Parry, M.L., Canziani, O.F., Palutikof, J.P., van der Linden, P.J., Hanson, C.E., Eds.; Cambridge University Press: Cambridge, UK, 2007; pp. 717-743.

49. O’Brien, K.; Leichenko, R.; Kelkar, U.; Venema, H.; Aandahl, G.; Tompkins, H.; Javed, A.; Bhadwal, S.; Barg, S.; Nygaard, L.; West, J. Mapping vulnerability to multiple stressors: Climate change and globalization in India. Glob. Environ. Change 2004, 14, 303-313.

50. Jouni, P.; Adger, W.N. Fair adaptation to climate change. Ecol. Econ. 2006, 56, 594-609.

51. Intergovernmental Panel on Climate Change (IPCC). Schneider, S.H.; Semenov, S.; Patwardhan, A.; Burton, I.; Magadza, C.H.D.; Oppenheimer, M.; Pittock, A.B.; Rahman, A.; Smith, J.B.; Suarez, A.; Yamin, F. Assessing Key Vulnerabilities and the Risk from Climate Change. In Climate Change 2007: Impacts, Adaptation and Vulnerability. Contribution of Working Group II 
to the Fourth Assessment Report of the Intergovernmental Panel on Climate Change; Parry, M.L., Canziani, O.F., Palutikof, J.P., van der Linden, P.J., Hanson, C.E., Eds.; Cambridge University Press: Cambridge, UK, 2007; pp. 779-810.

52. De Geus, M. Ecological Utopias: Envisioning the Sustainable Society; International Books: Utrecht, The Netherlands, 1999.

53. Benford Robert, D.; Snow David, A. Framing processes and social movements: An overview and assessment. Annu. Rev. Sociol. 2000, 26, 611-639.

54. Neal, P.; Palmer, J. Handbook of Environmental Education; Routledge: New York, NY, USA, 1994.

55. Committee on Climate Change Adaptation (CCC). How well prepared is the UK for climate Change? 2010. Available online: http://www.theccc.org.uk (accessed on 8 August 2010).

56. Abbott. J. Planning for complex metropolitan regions: A better future or a more certain one? J. Plan. Educ. Res. 2009, 28, 503-517.

57. Adger, W.N. Scales of governance and environmental justice for adaptation and mitigation of climate change. J. Int. Dev. 2001, 13, 921-931.

58. Heltberg, R.; Siegel, P.B.; Steen, L.J. Addressing human vulnerability to climate change: Toward a 'no-regrets' approach. Glob. Environ. Change 2009, 19, 89-99.

59. United Nations Development Programme (UNDP). Human Development Report 2002: Deepening Democracy in a Fragmented World; Oxford University Press: New York, NY, USA, 2002.

60. United Nations Framework Convention on Climate Change (UNFCCC). Climate Change: Impacts, Vulnerability and Adaptation in Developing Countries. Available online: http://unfccc.int (accessed on 11 August 2007).

61. Stern, N. The Stern Review on the Economics of Climate Change; Cambridge University Press: HM Treasury, UK, 2006.

62. Alberti, M.; Derek, B.; Kristina, H.; Bekkah, C.; Christina, A.; Stefan, C.; Daniele, S. The impacts of urban patterns on aquatic ecosystems: An empirical analysis in Puget Lowland Sub-Basins. Landsc. Urban Plann. 2007, 80, 345-361.

63. Pearce, D.; Barbier, E.; Markandya, A. Sustainable Development: Economics and Environment in the Third World; Earthscan Publications: London, UK, 1990; p. 1.

64. The Commission of the European Communities (CEC). White Paper: Adapting to Climate Change: Towards a European Framework for Action; CEC: Brussels, Belgium, 2009.

65. Bulkeley, H.; Newell, P. Governing Climate Change; Routledge: London, UK, 2010.

66. Johnson, J. Buying a sustainable economy: The record recovery act energy spending may trigger a new clean-energy industry. Chem. Eng. News 2009, 87, 17-22.

67. Beatley, T.; Manning, K. The Ecology of Place: Planning for Environment, Economy and Community; Island Press: Washington, DC, USA, 1998.

68. Jabareen, Y. Sustainable urban forms: Their typologies, models, and concepts. J. Plan. Educ. Res. 2006, 26, 38-52.

69. Wheeler, S.M. Constructing sustainable development/safeguarding our common future: Rethinnking sustainable development. J. Am. Plan. Assoc. 2002, 68, 110-111. 
70. United States Environmental Protection Agency (EPA). Our Built and Natural Environments: A Technical Review of the Interactions between Land Use, Transportation, and Rnvironmental Quality; EPA 231-R-01-002; EPA: Washington, DC, USA. Available online: http://www.smartgrowth.org (accessed on 3 September 2001).

71. Elkin, T.; McLaren, D.; Hillman, M. Reviving the City: Towards Sustainable Urban Development; Friends of the Earth: London, UK, 1991.

72. Jabareen, Y. Planning the resilient city: Concepts and strategies for coping with climate change and environmental risk. Cities 2012, forthcoming.

73. Jenks, M. The Acceptability of Urban Intensification. In Achieving Sustainable Urban Form; Williams, K., Burton, E., Jenks, M., Eds.; London: E \& FN SPON: London, UK, 2000.

74. Cervero, R. Coping with Complexity in America's Urban Transport Sector. In Proceeding of The 2nd International Conference on the Future of Urban Transport, Göteborg, Sweden, 22-24 September 2003.

75. Le Clercq, F.; Bertolini, L. Achieving sustainable accessibility: An evaluation of policy measures in the Amsterdam area. Built Environ. 2003, 29, 36-47.

76. Walker, L.; Rees, W. Urban Density and Ecological Footprints-An Analysis of Canadian households. In Eco-City Dimensions: Healthy Communities, Healthy Planet; Roseland, M., Ed.; New Society Publishers: Gabriola Island, BC, Canada, 1997.

77. Duncan, B.; Hartman, J. Sustainable Urban Transportation Initiatives in Canada. Paper submitted to the APEC Forum on Urban Transportation, Seoul, Korea, 20-22 November 1996.

78. Newman, P.; Kenworthy, J. Gasoline consumption and cities: A comparison of U.S. cities with a global survey. J. Am. Plan. Assoc. 1989, 55, 23-37.

79. Turner, S.R.S.; Murray, M.S. Managing growth in a climate of urban diversity: South Florida's Eastward ho! Initiative. J. Plan. Educ. Res. 2001, 20, 308-328.

80. Owens, S. Energy, Environmental Sustainability and Land-Use Planning. In Sustainable Development and Urban Form; Breheny, M., Ed.; Pion: London, UK, 1992; pp. 79-105.

81. Thomas, R. Building Design. In Sustainable Urban Design: An Environmental Approach; Thomas, R., Fordham, M., Eds.; Spon Press: London, UK, 2003; pp. 46-88.

82. Jacobs, J. The Death and Life of Great American Cities; Vintage Books: New York, NY, USA, 1961.

83. Forman, R.T. The Missing Catalyst: Design and Planning with Ecology. In Ecology and Design: Frameworks for Learning; Johnson Bart, T., Hill, K., Eds.; Island Press: Washington, DC, USA, 2002.

84. Carys, S.; Dunnett, N.; Woolley, H. Nature, role and value of green space in towns and cities: An overview. Built Environ. 2003, 29, 94-106.

85. Yanns, S. Living with the City: Urban Design and Environmental Sustainability. In Environmantly Friendly Cities; Eduardo, M., Yannas, S., Eds.; James \& James: London, UK, 1998; pp. 41-48.

86. Ulrich, R.S. Effects of Gardens on Health Outcomes: Theory and Research. In Healing Gardens: Therapeutic Benefits and Design Recommendations; Clare Cooper, M., Barnes, M., Eds.; Whiley: New York, NY, USA, 1999. 
87. Beer, A.; Delshammar, T.; Schildwacht, P. A changing understanding of the role of greenspace in high-density housing: A European perspective. Built Environ. 2003, 29, 132-143.

88. Dumreicher, H.; Levine, R.S.; Yanarella, E.J. The Appropriate Scale for "Low Energy": Theory and Practice at the Westbahnhof. In Architecture, City, Environment. Proceedings of PLEA 2000; Steemers, K., Simos, Y., Eds.; James \& James: London, UK, 2000; pp. 359-363.

89. Orr, D.K. All Hands on Deck: Teaching Sustainability. In 147 Practical Tips for Teaching Sustainability: Connecting the Environment, the Economy, and Society; Timpson, W.M., Dunbar, B., Kimmel, G., Bruyere, B., Vewman, P.I., Mizia, H., Eds.; Atwood Publishing: Madison, WI, USA, 2006.

90. Adams, R.; McCullough, A. The urban practitioner and participation in research within a streetwork context. Commun. Work Fam. 2003, 6, 269-288.

91. Reason, P.; Bradbury, H. Introduction: Inquiry and Participation in Search of a world Worthy of Human Aspiration. In Handbook of Action Research: Participative Inquiry and Practice; Reason, P., Bradbury, H., Eds.; Sage: London, UK, 2001.

92. Kagan, C.; Burton, M.; Siddiquee, A. Action Research. In The SAGE Handbook of Qualitative Research in Psychology; Willig, C., Stainton-Rogers, W. Eds.; Sage: London, UK, 2008. Available online: http://www.homepages.poptel.org.uk/mark.burton/actionresearchchapter\% 20v3\%20full.pdf (accessed on 11August 2008).

93. Jabareen, Y. Teaching Sustainability: A Multidisciplinary Approach. Creativ. Educ. 2011, 2, 388-392.

94. Jabareen, Y. Vulnerability of cities to extreme space weather events: A new frontier of a multidisciplinary urban research. Natural Science 2012 4, 368-371.

(C) 2012 by the authors; licensee MDPI, Basel, Switzerland. This article is an open access article distributed under the terms and conditions of the Creative Commons Attribution license (http://creativecommons.org/licenses/by/3.0/). 